\title{
Morphological Indexes: Can They Predict Lupus Nephritis Outcomes? A Retrospective Study
}

\author{
Índices Morfológicos na Nefrite Lúpica: Orientação \\ Prognóstica? Um Estudo Retrospetivo
}

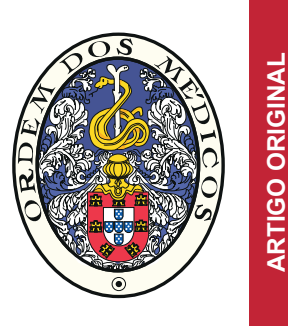

\author{
David NAVARRO $\square^{1}$, Ana Carina FERREIRA ${ }^{1}$, Helena VIANA ${ }^{1}$, Fernanda CARVALHO ${ }^{1}$, Fernando NOLASCO ${ }^{1}$ \\ Acta Med Port 2019 Oct;32(10):635-640 - https://doi.org/10.20344/amp.11598
}

\begin{abstract}
Introduction: Lupus nephritis is a serious complication of systemic lupus erythematosus. Currently, therapy is guided by findings in the renal biopsy, following the International Society of Nephrology / Renal Pathology Society classification. Austin and Hill's histomorphological indexes are not routinely obtained. In this retrospective single-centre study, we aimed to analyze the importance and applicability of the different morphological indexes in predicting response to treatment and prognosis.

Material and Methods: Patients with kidney biopsy demonstrating lupus nephritis from the $2010-2016$ period were included. We analyzed their demographic data, comorbidities, clinical presentation and laboratorial evaluation at the time of renal biopsy. We evaluated the following outcomes: clinical remission, renal function and proteinuria at end of follow-up. Histologic analysis was performed using the International Society of Nephrology / Renal Pathology Society classification and the morphological indexes described by Austin (Activity and Chronicity) and Hill. Univariate and multivariate statistical analysis was performed using STATA software.

Results: We analyzed 46 biopsy-proven lupus nephritis cases, with a median follow-up of 31.9 (13.2 - 45.6) months. Based on biopsy findings, 35 patients were started on immunosuppressive therapy. We observed that Class IV patients had, at presentation, lower estimated glomerular filtration rate $(67.3 \mathrm{vs} 94.6 \mathrm{~mL} / \mathrm{min} ; p=0.02)$, higher proteinuria $(4.26 \mathrm{vs} 2.37 \mathrm{~g} / 24 \mathrm{hours} ; p=0.02)$ and a non-significantly higher C3 consumption ( 58.9 vs $77.4 \mathrm{mg} / \mathrm{dL} ; p=0.06$ ). We did not observe correlations between International Society of Nephrology / Renal Pathology Society classification and the outcomes at the end of follow-up. In contrast, both the Hill biopsy index and Austin's Chronicity index were correlated with renal function and proteinuria at the end of follow-up. Austin's Activity index correlated with the immunological findings (C3, C4 and anti-dsDNA) at presentation.

Discussion: Because clinical activity poorly correlates with histologic activity, histological findings are fundamental when assessing patients with suspected lupus nephritis. The most recent International Society of Nephrology / Renal Pathology Society report supports the European League Against Rheumatism guidelines, encouraging the adoption of histomorphological indexes when evaluating lupus nephritis. Our data, showing a correlation between the renal outcomes and the indexes described by Austin and Hill, supports this view. Conclusion: The histomorphological indexes in lupus nephritis are easily obtainable, can predict renal outcomes and may help in the management of such patients.
\end{abstract}

Keywords: Biopsy; Kidney/pathology; Lupus Erythematosus, Systemic/complications; Lupus Nephritis Predictive Value of Tests; Prognosis

\section{RESUMO}

Introdução: A nefrite lúpica é uma complicação grave do lúpus eritematoso sistémica. Atualmente, a terapêutica dirigida é ditada pelos achados histológicos da biópsia renal, através da classificação da International Society of Nephrology / Renal Pathology Society. Os índices histomorfológicos descritos por Austin e Hill não são rotineiramente realizados. Neste estudo retrospetivo unicêntrico, procurámos analisar a aplicabilidade e relevância dos índices morfológicos na predição da resposta à terapêutica e do prognóstico em doentes com nefrite lúpica.

Material e Métodos: Foram incluídos doentes cuja biópsia renal, realizada entre 2010 e 2016, documentava nefrite lúpica. Analisámos os dados demográficos, comorbilidades, apresentação clínica e avaliação laboratorial destes doentes correspondente à altura da biópsia renal. Avaliámos os seguintes outcomes: remissão clínica, função renal e proteinúria no final do seguimento. A avaliação histológica foi realizada segundo a classificação da International Society of Nephrology / Renal Pathology Society e aplicando os índices morfológicos descritos por Austin (Actividade e Cronicidade) e Hill. A análise estatística univariada e multivariada foi realizada com software STATA.

Resultados: Foram revistos 46 casos de nefrite lúpica, com um follow-up mediano de 31,9 $(13,2-45,6)$ meses. A partir dos achados histológicos, 35 doentes foram submetidos a imunossupressão. Observámos que os doentes com nefrite lúpica Classe IV tinham, à apresentação, taxa de filtrado glomerular estimada mais reduzida $(67,3 \mathrm{vs} 94,6 \mathrm{~mL} / \mathrm{min} ; p=0,02)$, proteinúria mais elevada (4,26 vs $2,37 \mathrm{~g} / 24$ horas; $p=0,02)$ e consumo de C3 mais elevado de modo não-significativo $(58,9 \mathrm{vs} 77,4 \mathrm{mg} / \mathrm{dL} ; p=0,06)$. Não se verificou correlação entre a classificação ISN/RPS e os desfechos no final do follow-up. Por outro lado, tanto o índice de Hill quanto o score de cronicidade de Austin correlacionaram-se com a função renal e a proteinúria no final do seguimento. Adicionalmente, o score de atividade de Austin correlacionou-se com os achados imunológicos à apresentação (C3, C4 e anti-dsDNA).

Discussão: Uma vez que a actividade clínica tem fraca correlação com a actividade histológica, os achados histológicos são fundamentais durante a avaliação na suspeita de nefrite lúpica. A mais recente revisão da International Society of Nephrology / Renal Pathology Society vai ao encontro das linhas de orientação da European League Against Rheumatism, encorajando a aplicação de índices histomorfológicos na avaliação da nefrite lúpica. Os dados da nossa população, onde verificámos uma correlação entre o prognóstico renal e os índices histomorfológicos descritos por Austin e Hill, apoiam essa sugestão.

\footnotetext{
1. Nephrology Department. Hospital Curry Cabral. Centro Hospitalar Universitário de Lisboa Central. Lisbon. Portugal.

$\bowtie$ Autor correspondente: David Navarro. davidbnavarro@gmail.com

Recebido: 28 de novembro de 2018 - Aceite: 18 de abril de 2019 | Copyright $\odot$ Ordem dos Médicos 2019
} 
Conclusão: Os índices histomorfológicos na nefrite lúpica são de fácil aplicação, conseguem prever os outcomes clínicos e podem representar uma ferramenta adicional na avaliação dos doentes com nefrite lúpica.

Palavras-chave: Biópsia; Lupus Eritematoso Sistémico/complicações; Nefrite Lúpica; Prognóstico; Rim/patologia; Valor Preditivo dos Testes

\section{INTRODUCTION}

Systemic lupus erythematosus (SLE) is a systemic autoimmune disease associated with significant comorbidity and mortality. ${ }^{1}$ Lupus nephritis $(\mathrm{LN})$ is one of its most serious complications and includes a wide spectrum of clinical presentations, ranging from isolated haematuria to end-stage renal disease. Immunosuppression can have an important role in controlling renal affection - with current therapies, a high remission rate is observed, which is the most important renal prognostic factor. ${ }^{2}$ For those reasons, lupus nephritis requires a well-weighted diagnostic and therapeutic approach for which renal biopsy currently occupies a central role.

The International Society of Nephrology/Renal Pathology Society (ISN/RPS) lupus nephritis classification is widely used and recommended in current guidelines. ${ }^{3}$ Histology findings allow the sub-classification into six classes $(I-V I)$, as shown in Table 1. The most recent report ${ }^{4}$ and EULAR guidelines ${ }^{5}$ additionally recommend the use of morphological indexes; these have been originally described by Austin et al, ${ }^{6}$ who defined two indexes (activity and chronicity), using a semi-quantification of findings. This was further studied by Hill et al, ${ }^{7}$ who modified previous indexes, improving its prognostic value. Subcategorization of class III and IV into active, chronic or both is also suggested to be replaced by this semi-quantification method. ${ }^{4}$

Histomorphology has been of paramount importance in defining the field of nephrology. The quantification of microscopy findings has found its place in renal transplantation through the semi-quantitative Banff criteria. ${ }^{8}$ In LN, while the ISN/RPS classification is routinely used, Austin and Hill indexes are not. The aim of this study was to analyze the applicability and the efficacy of the different LN morphological indexes in predicting response to treatment and prognosis.

\section{MATERIAL AND METHODS}

This is a retrospective single-centre descriptive analysis of consecutive SLE and biopsy-proven LN patients, diagnosed from 2010 to 2016. Patients whose kidney biopsies were found to be inadequate due to an insufficient number of glomeruli (defined as less than five) were excluded.

Table 1 - Abbreviated lupus nephritis ISN/RPS classification

\begin{tabular}{ll}
\hline Class & Definition \\
\hline Class I & Minimal mesangial lupus nephritis \\
Class II & Mesangial proliferative lupus nephritis \\
Class III & Focal lupus nephritis \\
Class IV & Diffuse lupus nephritis \\
Class V & Lupus membranous nephropathy \\
Class VI & Advanced sclerosing lupus nephritis \\
\hline
\end{tabular}

Patients' data were obtained from clinical files. We analyzed patients' demographic data (age, gender, race), comorbidities and their duration (including SLE history and previous manifestations and medications), hypertension according to the most recent definition by the European Society of Cardiology, ${ }^{9}$ clinical presentation and laboratorial evaluation at the time of renal biopsy [including full blood count, serum creatinine, urinalysis, proteinuria (24 hours-collection or urinary protein to creatinine ratio in a random urine sample), C3, C4 and anti-dsDNA].

The following outcomes were evaluated: clinical remission, renal function and proteinuria ( $g / 24$ hours) at end of follow-up (FUP). The LUNAR trial ${ }^{10}$ definition for clinical remission was used: complete remission was defined as reduction of proteinuria to $<0.5 \mathrm{~g} / 24$ hours, inactive urinary sediment and normal serum creatinine level if it was abnormal at baseline (or a serum creatinine level of $<115 \%$ of baseline if it was normal at baseline); partial remission was defined as a reduction in proteinuria to $<1 \mathrm{~g} / 24$ hours if initial level $<3 \mathrm{~g} / 24$ hours (or reduction to $<3 \mathrm{~g} / 24$ hours if initial level $>3 \mathrm{~g} / 24$ hours), inactive urinary sediment and a serum creatinine level of $<115 \%$ of baseline. All renal biopsies were performed after obtaining the patient's written consent. The histologic optic examination was performed with hematoxylin and eosin, periodic acid-Schiff, Jones' silver and Masson's trichrome stains; immunofluorescence study included studies with antibodies against IgG, IgA, IgM, C3, C4, C1q and fibrinogen.

The studied predictors were the ISN/RPS LN classification and the morphological indexes described by Austin (activity and chronicity) ${ }^{6}$ and Hill, ${ }^{7}$ obtained after histomorphological review of renal biopsies. Both scores describe findings in a quantitative fashion (zero to $3+$ ). Austin's activity score measures active $L N$ findings of glomerular proliferation, leucocyte exudation/karyorrhexis, fibrinoid necrosis, cellular crescents, hyaline deposits and interstitial inflammation; Austin's chronicity score contains chronic irreversible LN findings: glomerular sclerosis, fibrous crescents, tubular atrophy and interstitial fibrosis.

Hill's biopsy index slightly adapted Austin's activity and chronicity scores and added histological signs of tubulointerstitial activity (including tubular cell necrosis and flattening and the presence of macrophages or epithelial cells in tubular lumens) and immunofluorescence findings (including glomerular, tubulointerstitial and vascular deposition). Regarding the latter, in the review of our samples, we did not re-perform immunofluorescence and instead used the findings described in our original report. Table 2 summarizes both indexes.

Renal function was monitored by serum creatinine and estimated glomerular filtration rate (eGFR) using the Chronic Kidney Disease Epidemiology Collaboration (CKD-EPI) equation. 
Table 2 - Morphological indexes scoring system. (A) Austin's activity and chronicity indexes; (B) Hill biopsy index

A:

\begin{tabular}{ll}
\hline Activity index & Score \\
\hline Endocapillary hypercellularity & $0-3$ \\
Neutrophils/karyorrhexis & $0-3$ \\
Fibrinoid necrosis & $(0-3) \times 2$ \\
Hyaline deposits & $0-3$ \\
Cellular/fibrocellular crescents & $(0-3) \times 2$ \\
Interstitial Inflammation & $0-3$ \\
Total & $0-24$ \\
\hline Chronicity index & Score \\
\hline Total glomerulosclerosis score & $0-3$ \\
Fibrous crescents & $0-3$ \\
Tubular atrophy & $0-3$ \\
Interstitial fibrosis & $0-3$ \\
Total & $0-12$ \\
\hline
\end{tabular}

Data are presented as frequencies for categorical variables; continuous variables are presented as median (interquartile range).

One-way ANOVA was used for comparisons between the different indications for kidney biopsy, the laboratory data and the morphologic data obtained after the application of the different morphological indexes; chi-square test of independence/Fisher's exact test was performed when comparing the different indications for kidney biopsy and the ISN/RPS LN classes. Associations between the different LN classes and clinical and laboratory variables were investigated using Fisher's exact test and Wilcoxon. Associations between Austin and Hill indexes and laboratory variables were investigated using Spearman test.

After this first analysis, we fitted a model of multivariate analysis using all subjects and defining the chronicity indexes as our main predictors and eGFR at the end of follow-up as our main outcome. Age, gender and proteinuria were the variables used as potential confounders (older patients may have a lower renal function, women tend to have lower GFR and proteinuria is associated with a rapid decline of renal function). All tests were performed using STATA software
B:

\begin{tabular}{ll}
\hline Components & Score \\
\hline Glomerular Activity index & $0-3$ \\
Tubulointerstitial Activity index & $0-4$ \\
Chronic lesions index & $0-2$ \\
Immunofluorescence index & $0-3$ \\
Total & $\mathbf{0 - 1 2}$ \\
\hline
\end{tabular}

version 13 , and a $p$-value $<0.05$ was considered statistically significant.

Given the nature of this analysis (retrospective and observational) and the anonymization of the collected data, authorization from the ethics committee and the Portuguese Data Protection Authority was not required.

\section{RESULTS}

From 2010 to 2016, we found 46 biopsy-proven LN cases in our unit. The patients' median age was 35 years $(27-42)$, and $84.8 \%(n=39)$ were women, in a mostly Caucasian population $(56.5 \% ; n=26)$. In seven patients, SLE diagnosis was previously unknown, while the remaining 39 patients had SLE for a median of $3.96(1.1-11.9)$ years, resulting in treatment with hydroxychloroquine in $46.1 \%$ and additional immunomodulation in $76.9 \%$ of cases. At presentation, median creatinine was $0.8(0.6-1.4)$ $\mathrm{mg} / \mathrm{dL}$, corresponding to a median eGFR of $89(46.9-117)$ $\mathrm{mL} / \mathrm{min}$; median level of proteinuria was $2.45(1-4.4) \mathrm{g} / \mathrm{day}$; $34.7 \%(n=16)$ of patients were hypertensive and $58.7 \%$ $(n=27)$ had haematuria at presentation. We classified our patients according to the indication for renal biopsy: 18 had asymptomatic urinary abnormalities, 16 nephrotic-range proteinuria (proteinuria $>3.5 \mathrm{~g} / \mathrm{d}$ ) and 12 renal insufficiency (eGFR $<45 \mathrm{ml} / \mathrm{min}$ ). The histomorphological findings are summarized in Table 3.

Regarding histology, sample quality was adequate, the minimum number of glomeruli per sample was five and we had a maximum of 30 glomeruli, with a median of 11 glomeruli $(7.75-14.25)$. The 46 patients were evaluated during a median follow-up of 31.9 months $(13.2-45.6)$ months.

Table 3 - Renal clinical characteristics and histomorphology findings

\begin{tabular}{|c|c|c|c|c|c|c|c|c|}
\hline Clinical presentation & Patients & Class II & Class III & Class IV & Class V & $\begin{array}{c}\text { Austin's } \\
\text { Activity Index }\end{array}$ & $\begin{array}{l}\text { Austin's } \\
\text { Chronicity } \\
\text { Index }\end{array}$ & $\begin{array}{l}\text { Hill Biopsy } \\
\text { Index }\end{array}$ \\
\hline $\begin{array}{l}\text { Asymptomatic urinary } \\
\text { abnormalities }\end{array}$ & 18 & $44 \%$ & $17 \%$ & $28 \%$ & $11 \%$ & $\begin{array}{c}3.03 \\
(0-6)\end{array}$ & $\begin{array}{c}1.50 \\
(0-2.63)\end{array}$ & $\begin{array}{c}0.86 \\
(0.14-1.53)\end{array}$ \\
\hline $\begin{array}{l}\text { Nephrotic syndrome } \\
\text { (proteinuria > } 3.5 \mathrm{~g} / \mathrm{d} \text { ) }\end{array}$ & 16 & $0 \%$ & $25 \%$ & $63 \%$ & $31 \%$ & $\begin{array}{c}6.59 \\
(1.65-10)\end{array}$ & $\begin{array}{c}2.66 \\
(1-3)\end{array}$ & $\begin{array}{c}1.63 \\
(0.76-2.27)\end{array}$ \\
\hline $\begin{array}{l}\text { Renal insufficiency } \\
(\text { eGFR }<45 \mathrm{ml} / \mathrm{min})\end{array}$ & 12 & $0 \%$ & $8 \%$ & $75 \%$ & $17 \%$ & $\begin{array}{c}6.95 \\
(0.5-13)\end{array}$ & $\begin{array}{c}3.73 \\
(0.5-7)\end{array}$ & $\begin{array}{c}1.96 \\
(1.56-2.56)\end{array}$ \\
\hline$p$-value & - & $<0.001$ & NS & 0.02 & NS & 0.07 & 0.08 & 0.007 \\
\hline
\end{tabular}

eGFR: estimated glomerular filtration rate; NS: non-significant. LN Classes (from II to V) frequencies are expressed for each renal clinical characteristic (asymptomatic urinary abnormalities | nephrotic syndrome | renal disease). Median indexes (Austin activity and chronicity and Hill biopsy) are expressed for each renal clinical characteristic (asymptomatic urinary abnormalities | nephrotic syndrome | renal disease). The analysis of the proportions between renal characteristics and LN classes was performed using Fisher exact test; the analysis of the variance of the different indexes was performed using one-way ANOVA. 
Based on biopsy findings, immunosuppressive therapy was started/intensified on 36 patients — induction therapy with cyclophosphamide in $50 \%$ and mofetil mycophenolate (MMF) in the remaining 50\%; MMF was used as maintenance therapy in $80.6 \%(n=29)$ of patients, azathioprine being the choice for the other seven patients. Excluding patients with ongoing induction immunosuppression, clinical remission was obtained in $93.8 \%$ (30/32) of patients we observed 15 complete, 15 partial remissions and four patients suffered $L N$ recurrence.

By the end of follow-up, two patients (4.3\%) died due to septic shock, one of them having developed end-stage renal disease secondary to $L N$. The remaining 95.7\% ( $n=44)$ had a median serum creatinine of $0.8 \mathrm{mg} / \mathrm{dL}(0.7-0.99)$, eGFR of $99.8 \mathrm{~mL} / \mathrm{min}(71.2$ - 116.8) and proteinuria of $0.6 \mathrm{~g} / 24$ hours $(0.2-1.6)$.

Using Wilcoxon test, we observed that patients classified as ISN/RPS class IV had, at presentation, lower eGFR ( 67.3 vs $94.6 \mathrm{~mL} / \mathrm{min} ; p=0.01$ ), higher proteinuria (4.26 vs $2.37 \mathrm{~g} / 24$ hours; $p=0.002$ ) and non-significant reduction in C3 serum levels (58.9 vs $77.4 \mathrm{mg} / \mathrm{dL} ; p=0.06$ ). We found no correlation between the different ISN/RPS LN classes and clinical outcomes, including end of follow-up renal function or proteinuria. We did, however, find several correlations between clinical findings (both at presentation and at the end of follow-up) and the activity and chronicity histomorphological indexes, as described in Table 4.

Using the Spearman test, we observed that the Activity index correlated with the immunological findings at presentation - C3, C4 and anti-dsDNA. More importantly, both the Hill biopsy index and the Chronicity index were correlated with renal function and proteinuria at the end of follow-up, and hence a predictor of unsuccessful clinical remission. No individual histological finding of the indexes could, by itself, predict clinical remission.

In the multivariate model, the chronicity index was inversely correlated with eGFR, using age, gender, and initial proteinuria as potential confounders ( $p$-value of the model 0.02).

\section{DISCUSSION}

Management of SLE patients can be complex, being especially challenging to attain disease control without causing iatrogenesis. For this reason, many efforts are put into the elaboration and refining of disease activity indexes. ${ }^{11}$ The same holds true for LN, especially since some of the clinical parameters we rely on for renal disease (serum creatinine and proteinuria) can represent both active disease - that may be treated with further immunosuppression - and chronic damage - which would not benefit from additional immunomodulation. For those reasons, clinical remission definitions in $L N$ are many and rarely agreed upon. ${ }^{12}$ More importantly, clinical activity poorly correlates with histologic activity, ${ }^{13}$ further complicating clinical decisions. To mitigate this, some centers are routinely performing repeat renal biopsies regardless of clinical indication. ${ }^{14}$

Nephrologists rely heavily on histomorphological findings in LN, and general agreement is that immunosuppression should be started when the ISN/RPS classification suggests the patient has an active proliferative disease (class III or IV with activity signs) or a severe membranous LN (class V); treating renal affection with immunosuppressive drugs for other classes is typically not recommended. Some limitations to the ISN/RPS classification need to be considered, starting with the fact that it is, by definition, glomerulocentric, leaving little to no space to the description of the full spectrum of histomorphological manifestations of LN. This confers an almost dichotomic-aura (i.e. treat / don't treat) to the current classification and hampers the introduction of diagnostic subtleties such as lupus podocytopathy. ${ }^{15}$ Another issue is that while nephrologists are sensible to findings such as tubular atrophy and interstitial fibrosis, until the last update, ISN/RPS failed to account for tubulointerstitial lesions adequately. Injury to the tubulointerstitial compartment appears to poorly correlate with glomerular lesions, ${ }^{16,17}$ suggesting independent immunological pathways, which were oversimplified by the ISN/RPS classification - this raises the question if the tubulointerstitial activity should itself be an indication for immunosuppressive

Table 4 - Correlations between clinical parameters and histomorphological indexes

\begin{tabular}{|c|c|c|c|c|c|c|}
\hline & \multicolumn{2}{|c|}{ Austin's Activity Index } & \multicolumn{2}{|c|}{ Austin's Chronicity Index } & \multicolumn{2}{|c|}{ Hill Biopsy Index } \\
\hline & $\mathrm{R}$ & $p$ & $\mathrm{R}$ & $p$ & $\mathrm{R}$ & $p$ \\
\hline \multicolumn{7}{|l|}{ Presentation } \\
\hline Anti-dsDNA (IU/mL) & 0.3 & 0.05 & -0.07 & NS & 0.2 & NS \\
\hline C3 (mg/dL) & -0.3 & 0.03 & 0.1 & NS & -0.2 & NS \\
\hline $\mathrm{C} 4(\mathrm{mg} / \mathrm{dL})$ & -0.3 & 0.04 & 0.1 & NS & -0.2 & NS \\
\hline Serum creatinine $(\mathrm{mg} / \mathrm{dL})$ & 0.1 & NS & 0.3 & 0.03 & 0.3 & 0.03 \\
\hline eGFR (ml/min) & -0.3 & NS & -0.4 & 0.004 & -0.5 & 0.001 \\
\hline Proteinuria (g/24h) & 0.4 & 0.009 & -0.3 & 0.006 & 0.6 & 0.0001 \\
\hline \multicolumn{7}{|l|}{ End of follow-up } \\
\hline Serum creatinine (mg/dL) & 0.07 & NS & 0.4 & 0.002 & 0.3 & 0.046 \\
\hline eGFR (mL/min) & 0.09 & NS & -0.5 & 0.002 & -0.2 & NS \\
\hline Proteinuria (g/24h) & 0.2 & NS & 0.3 & 0.03 & 0.4 & 0.02 \\
\hline
\end{tabular}

eGFR: estimated glomerular filtration rate. All correlations were made using Spearman correlation in a univariate analysis. 
therapy. Furthermore, and perhaps most importantly, there is an increasing body of evidence showing that tubulointerstitial lesions are the most significant prognostic indicator in LN. ${ }^{17,18}$ It is therefore not surprising that, despite being extensively used, the ISN/RPS classification could not predict clinical outcomes. This has led to the development of the indexes described by Austin and later by Hill, which have proven capable of estimating renal outcomes from the renal biopsy findings. Their integration in the most recent ISN/RPS classification reflects its importance. In an era of a continuous search for more sophisticated therapeutic strategies, ${ }^{19,20}$ it's surprising that so little emphasis had been given to improve upon our current clearly insufficient diagnostic methods. Despite being 'old news', morphological indexes have the potential to introduce a more refined approach to diagnosis and treatment, similar to what the Banff criteria offer to the renal transplantation field.

Our first goal was to evaluate the applicability of such scores: despite not being familiar with them and requiring an additional effort, we had no substantial difficulty in their application. The second goal was to evaluate their usefulness in predicting response to treatment and prognosis. As shown in Table 3, we observed an association between clinical presentation and the ISN/RPS classification. The same is valid for Hill's biopsy index and Austin's Activity and Chronicity indexes. However, when considering outcomes at the end of follow-up, the ISN/RPS classification added little, while the morphological indexes can predict outcomes (Table 4).

Based on these findings, although we feel morphological indexes are useful in LN, some limitations are observable: i) we only reviewed light microscopy findings and did not re-perform immunofluorescence; ii) it is a retrospective single-centre study, with a fairly low number of patients limiting our conclusions - for instance, we would have liked to further examine the role of the indexes with different

\section{REFERENCES}

1. Cervera R, Khamashta MA, Font J, Sebastiani GD, Gil A, Lavilla P, et al. Morbidity and mortality in systemic lupus erythematosus during a 10-year period. Medicine. 2003;82:299-308.

2. Korbet SM, Lewis EJ, Schwartz MM, Reichlin M, Evans J, Rohde RD, et al. Factors predictive of outcome in severe lupus nephritis. Lupus. 2000;35:904-14

3. Kidney Disease Improving Global Outcomes. KDIGO Clinical practice guideline for glomerulonephritis. Kidney Int Suppl. 2012;2:1-274.

4. Bajema IM, Wilhelmus S, Alpers CE, Bruijn JA, Colvin RB, Cook HT, et al. Revision of the International Society of Nephrology/Renal Pathology Society classification for lupus nephritis: clarification of definitions, and modified National Institutes of Health activity and chronicity indices. Kidney Int. 2018;93:789-96.

5. Bertsias GK, Tektonidou M, Amoura Z, Aringer M, Bajema I, Berden JH, et al. Joint European League Against Rheumatism and European Renal Association-European Dialysis and Transplant Association (EULAR/ ERA-EDTA) recommendations for the management of adult and paediatric lupus nephritis. Ann Rheum Dis. 2012;71:1771-82.

6. Austin HA, Muenz LR, Joyce KM, Antonovych TA, Kullick ME, Klippel $\mathrm{JH}$, et al. Prognostic factors in lupus nephritis. Contribution of renal histologic data. Am J Med. 1983;75:382-91.

7. Hill GS, Delahousse M, Nochy D, Tomkiewicz E, Remy P, Mignon F, et al. A new morphologic index for the evaluation of renal biopsies in lupus nephritis. Kidney Int. 2000;58:1160-73.

8. Loupy A, Haas M, Solez K, Racusen L, Glotz D, Seron D, et al. The immunosuppressive drugs, which were not apparent in our population. Further analysis with a larger number of patients could shed some light on this subject, potentially identifying the patients who require a more aggressive therapeutic approach.

\section{CONCLUSION}

In summary, the most recent ISN/RPS consensus recognizes the efficacy of histomorphological indexes in the evaluation of LN, and our data supports that. We observed a significant correlation between the renal outcomes and the indexes described by Austin and Hill. We encourage other units to include morphological indexes in their evaluation of such patients, as they are easily applicable scores and may provide a useful and individualized quantitative measure of clinical outcomes.

\section{PROTECTION OF HUMANS AND ANIMALS}

The authors declare that the procedures were followed according to the regulations established by the Clinical Research and Ethics Committee and to the Helsinki Declaration of the World Medical Association.

\section{DATA CONFIDENTIALITY}

The authors declare having followed the protocols in use at their working centre regarding patients' data publication.

\section{CONFLICTS OF INTEREST}

The authors declare no potential conflicts of interest with respect to the research, authorship, and/or publication of this article.

\section{FUNDING SOURCES}

The authors received no financial support for the research, authorship, and/or publication of this article.

Banff 2015 Kidney Meeting Report: Current Challenges in Rejection Classification and Prospects for Adopting Molecular Pathology. Am J Transplant. 2017;17:28-41.

9. Williams B, Mancia G, Spiering W, Agabiti Rosei E, Azizi M, Burnier M, et al. 2018 ESC/ESH Guidelines for the management of arterial hypertension. Eur Hear J. 2018;39:3021-104.

10. Rovin BH, Furie R, Latinis K, Looney RJ, Fervenza FC, SanchezGuerrero J, et al. Efficacy and safety of rituximab in patients with active proliferative lupus nephritis: the Lupus Nephritis Assessment with Rituximab study. Arthritis Rheum. 2012;64:1215-26.

11. Rao V, Gordon C. Advances in the assessment of lupus disease activity and damage. Curr Opin Rheumatol. 2014;26:510-9.

12. Corapi KM, Dooley MA, Pendergraft WF. Comparison and evaluation of lupus nephritis response criteria in lupus activity indices and clinical trials. Arthritis Res Ther. 2015;17:110.

13. Malvar A, Pirruccio P, Alberton V, Lococo B, Recalde C, Fazini B, et al. Histologic versus clinical remission in proliferative lupus nephritis. Nephrol Dial Transplant. 2017;32:1338-44.

14. Zickert A, Sundelin B, Svenungsson E, Gunnarsson I. Role of early repeated renal biopsies in lupus nephritis. Lupus Sci Med. 2014;1:e000018.

15. Bomback AS, Markowitz GS. Lupus podocytopathy: a distinct entity. Clin J Am Soc Nephrol. 2016;11:547-8.

16. Clark MR, Trotter K, Chang A. The Pathogenesis and therapeutic implications of tubulointerstitial inflammation in human lupus nephritis. 
Semin Nephrol. 2015;35:455-64.

17. Hsieh C, Chang A, Brandt D, Guttikonda R, Utset TO, Clark MR. Predicting outcomes of lupus nephritis with tubulointerstitial inflammation and scarring. Arthritis Care Res. 2011;63:865-74.

18. Pagni F, Galimberti S, Galbiati E, Rebora P, Pietropaolo V, Pieruzzi F, et al. Tubulointerstitial lesions in lupus nephritis: International multicentre study in a large cohort of patients with repeat biopsy. Nephrology.
2016;21:35-45

19. Dall'Era M. Treatment of lupus nephritis. Curr Opin Rheumatol. 2017;29:241-7.

20. Dobronravov V, Dooley MA, Haq SA, Adzerikho I, Bugrova O, Isenberg D, et al. LB0002 48 week complete remission of active lupus nephritis with voclosporin. Ann Rheum Dis. 2017;76:153 LP. 